$\xi=1$ -

\title{
A comparative analysis of rectangular cut edge patch antenna on various substrate
}

\author{
Sachidananda Choudhury ${ }^{1}$, Veeranki Kalyani ${ }^{1}$, R. Sai Teja ${ }^{1}$, P. Sreenivasan ${ }^{1}$, \\ Sarat K. Kotamraju ${ }^{2 *}$, K. Ch. Sri Kavya ${ }^{2}$ \\ ${ }^{1}$ B.Tech Final Year, Department of ECE, Koneru Lakshmaiah Educational Foundation, Guntur Dist., Andhra Pradesh, India \\ ${ }^{2}$ Professor, Department of ECE, Koneru Lakshmaiah Educational Foundation, Guntur Dist., Andhra Pradesh, India \\ *Corresponding author E-mail: kksarat@gmail.com
}

\begin{abstract}
An analysis of simple microstrip patch antenna has been designed which comprises of various dielectric substrates that is placed in between metallic patch and ground. Substrates used in this design Epoxy (FR4), Rogers duroid 6002 (tm) with various relative permittivity 2.94 and 2.2 and thickness of $3.2 \mathrm{~mm}$. Some applications for the designed frequency are wireless fidelity, WLAN application, Bluetooth. The proposed antenna is designed in HFSSV15 Software operating at $2.4 \mathrm{GHz}$ frequency which renders return loss not more than -10dB. The purpose of this paper was analyzation and simulation for the designed antenna with various parameters like gain, peak gain, efficiency, return loss, band-width when the structure and substrate changes.
\end{abstract}

Keywords: Bandwidth; Efficiency; Gain; Microstrip patch; Peak gain; Radiation pattern, Return loss.

\section{Introduction}

Micro strip radiating element was introduced in the year 1950s. An antenna generally helps in converting an RF signal, conductor that can be travelled through, in free space guided by electromagnetic wave, and vice versa (which means either in receiving mode as well as in transmitting mode also). Antennas mostly depend upon the frequency. Whenever we need to radiate or receive electromagnetic wave we can use antenna. There are various shapes and structure that an antenna can be designed, but the basic principle of operation is electromagnetic. Various portable electronic devices require an actual and effectual antenna for wireless communication. Developments in digital and wireless microchip technology have led to the manufacture of an innovative type of subjective communications equipment affectation unusual problems for antenna designers. Peculiar wireless communication policies have created a bigger request for compressed antennas. Moreover, the development of wireless local area networks at work and home has also demanded the claim for radiating element that is compressed as well as low-cost.

Till date microstrip patch antenna is the maximum successful antenna. Actually microstrip patch antennas are used in broad range frequencies ranging from $1 \mathrm{GHz}$ to $100 \mathrm{GHz}$. Micro strip patch antenna is planar but it also suitable for non-planar geometries, components are easily integrated, robustness mechanically, association of arrays. The main advantages of microstrip patch antennas are its light weight and low profile, due to these reasons they can be built easily and also the fabrication costs low[13-18]. In parallel there are also disadvantages like inherent narrow bandwidth and low efficiency. The drawbacks of micro strip antennas are overcome by developing the techniques to increase the bandwidth and a very wideband micro strip antennas are presented.

The applications of micro strip antennas are many in number and military applications and commercial applications such as radar, biomedicines, satellite communications, mobile applications, wireless area network, ultra-wide band application and identification of radio frequency.

We generally consider rectangular microstrip patch antenna as the maximum likely antenna that can be required for designing microstrip patch antennas that contains dimension like length and breadth with letter L and B respectively. We can use various types of substrate based on our requirement. The various Substrate used in this paper is FR4 Epoxy with relative permittivity $=4.4$, Rogers duroid $5880(\mathrm{tm})$, relative permittivity $=2.2$ and Rogers $\mathrm{RT} /$ duroid $6002(\mathrm{tm})$ relative permittivity $=2.94$. The substrate is placed in between the ground plane and the patch.

The remaining part of the paper is ordered as follows: where section 2 is on design topology of an antenna. The simulation results of a designed antenna are represented in section 3. Finally, paper is concluded with conclusion and future scope with section 4 and section 5 respectively.

\section{Design Topology}

The Antenna designed in this paper is printed by three layers, top one is patch which is placed on a substrate and then followed by ground plane. Coaxial feed is given for the designed micro strip patch antenna. The internal conductor is prolongs transversely to the dielectric and is associated at the radiating component, while the external conductor of a coaxial connector attached at ground plane. Fig. 1 shows the feeding technique used in this paper. 


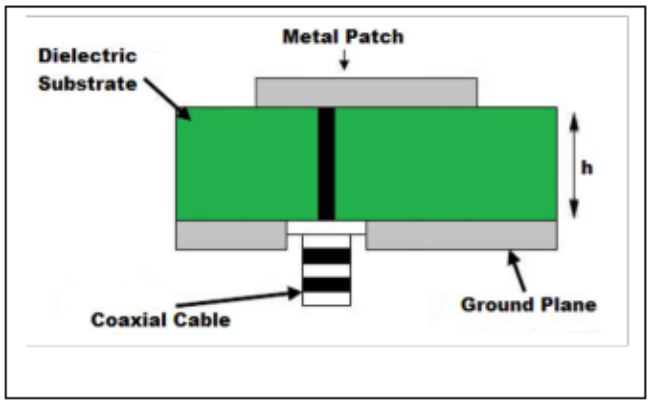

Fig. 1 Coaxial probe feed

But this turn outs a narrow bandwidth and modelling is difficult which is a disadvantage for this technique. Various Substrate were used for the designed such as substrate material like FR-4, Roger RT.

Table 1: Substrate and its Relative Permittivity

\begin{tabular}{|c|c|}
\hline Substrate Material & Relative Permittivity \\
\hline FR4 EXPROXY & 4.4 \\
\hline Rogers RT/duroid 5880 (tm) & 2.2 \\
\hline Rogers RT/duroid 6002 (tm) & 2.94 \\
\hline
\end{tabular}

In the Fig.2, it shows the designed antenna from the top view, Fig. 3 shows the designed antenna from the top view having some cutting edges, Fig. 4 shows the side view of the designed antenna. The antenna is fabricated on $100 \times 90 \mathrm{~mm} 2$ and all the substrate with thickness of $3.2 \mathrm{~mm}$. A simple patch antenna is placed on the substrate(Roger Rogers RT/duroid $5880(\mathrm{tm})$ ) where the coaxial feed position is at $(-5,0,-5)$ named as Antenna 1, patch but with feed position is changed to $(-5,5,-5)$ named as Antenna 2, patch with some cutting edges and coaxial feed position at $(-5,0,-5)$ named as antenna 3 , patch with some cutting edges and coaxial feed position at $(-5,5,-5)$ named as antenna 4 . Now the substrate used is FR4 Epoxy and patch placed on it at feed position $(-5,0,-5)$ is named as Antenna 5, patch but with feed position changed to ($5,5,-5)$ named as Antenna 6, patch with some cutting edges and feed position at $(-5,0,-5)$ named as antenna 7 , patch with some cutting edges and feed position at $(-5,5,-5)$ named as antenna 8 . Another Substrate Rogers RT/duroid 6002 (tm) and the patch placed on it at coaxial feed position $(-5,0,-5)$ is named as Antenna 9 , patch but feed position is changed to $(-5,5,-5)$ named as Antenna 10 , patch with some cutting edges and feed position at $(-5,0,-5)$ named as antenna 11, patch with some cutting edges and feed position at $(-5,5,-5)$ named as antenna 12 .

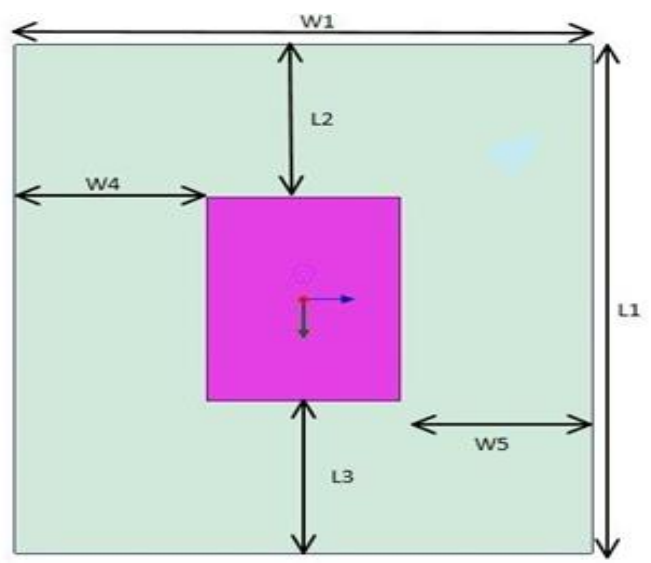

Fig. 2: Designed antenna from top view

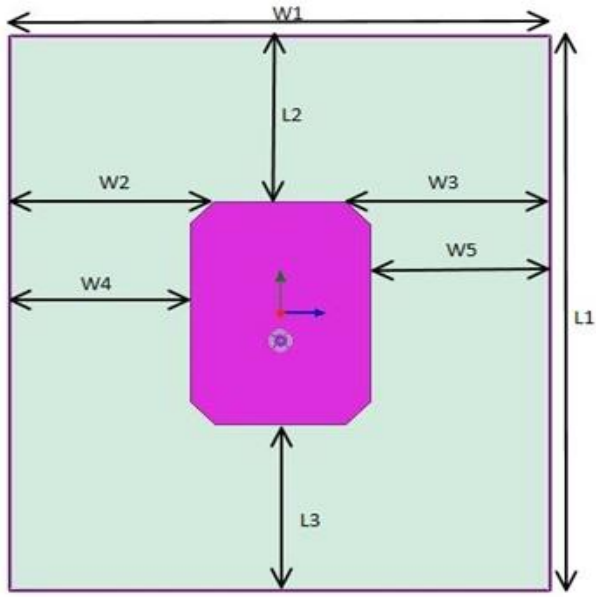

Fig. 3: Designed antenna with cutting edges from top view

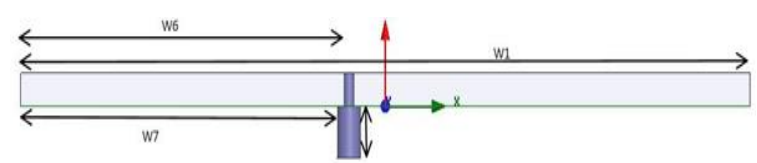

Fig.4: Designed antenna from side view

Table 2: Dimensions for designed antenna Dimensions in $\mathrm{mm}$

\begin{tabular}{|c|c|c|}
\hline W1 & W2 & W3 \\
\hline 90 & 34 & 34 \\
\hline W4 & W5 & W6 \\
\hline 30 & 30 & 45 \\
\hline W7 & L1 & L2=L3 \\
\hline 43.5 & 100 & 30 \\
\hline
\end{tabular}

\section{Results and Discussion}

\subsection{Return Loss}

It is the power loss when the signal is reverted by transmission lines discontinuity. Its relation is based on reflection coefficient and standing wave ratio (SWR). We can express return loss in form of, $\mathrm{RL}=-20 \log [\mathrm{L}]$

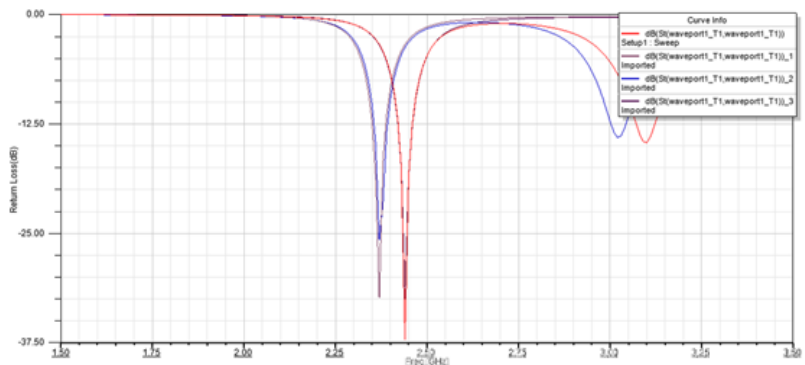

Fig. 5: Return loss for microstrip patch antenna (Roger RT/duroid 5880 $(\mathrm{tm}))$

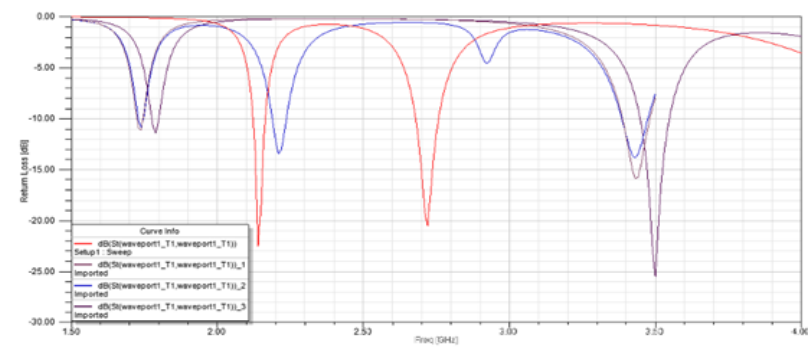

Fig. 6: Return loss for microstrip patch antenna (FR4 Epoxy) 


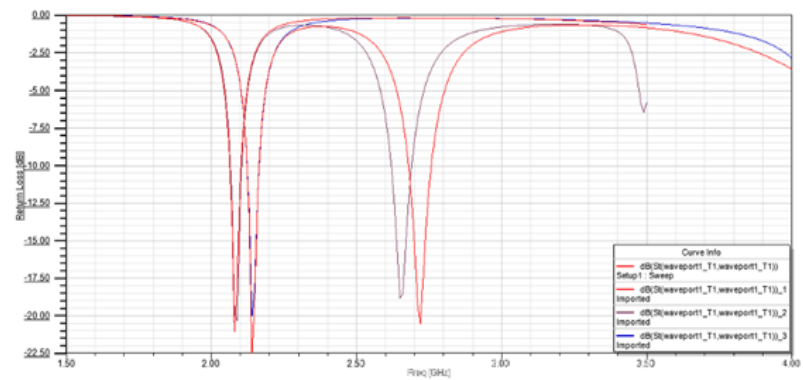

Fig. 7: Return loss for microstrip patch antenna (Roger RT/duroid 6002 (tm)

\subsection{Gain}

Gain is defined as the ratio of radiation field intensity of test antenna to that of the reference antenna.

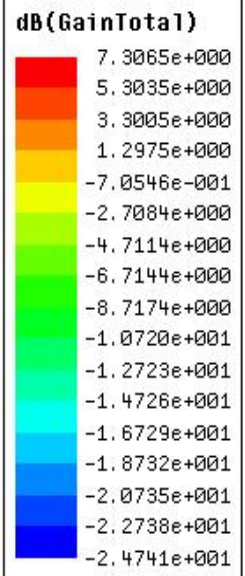

Fig: 8: Gain for Antenna 1

dB (GainTota1)
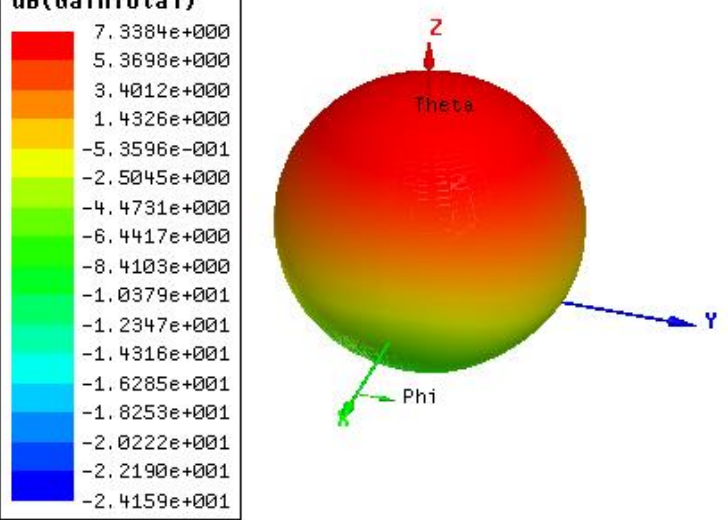

Fig: 9: Gain for Antenna 2

\section{dB (GainTota 1)}

\begin{tabular}{|c|}
\hline $\begin{array}{l}7.2584 e+000 \\
5.3970 e+000\end{array}$ \\
\hline \\
\hline $\begin{array}{l}3.3557 e+000 \\
1.4044 e+000\end{array}$ \\
\hline$-5.4697 e-001$ \\
\hline$-2.4983 e+000$ \\
\hline$-4.4496 e+000$ \\
\hline$-6.4010 e+000$ \\
\hline$-8.3523 e+000$ \\
\hline$-1.0304 e+001$ \\
\hline$-1.2255 e+001$ \\
\hline$-1.4206 e+001$ \\
\hline$-1.6158 e+001$ \\
\hline$-1.8109 e+001$ \\
\hline$-2.0060 e+001$ \\
\hline$-2.2012 e+001$ \\
\hline \\
\hline
\end{tabular}

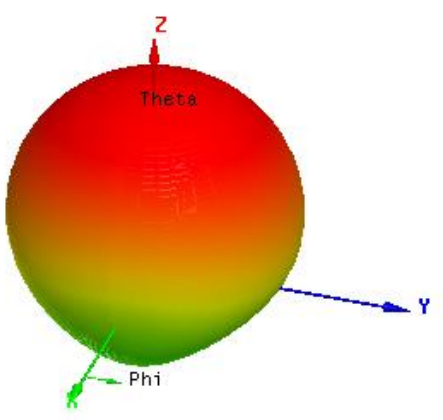

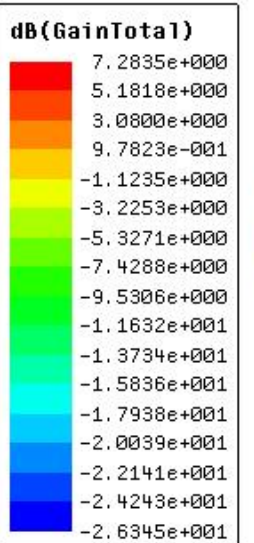

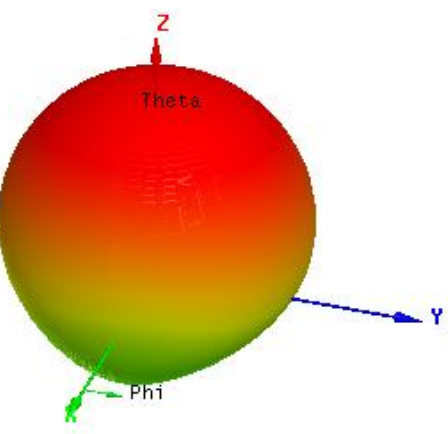

Fig: 11: Gain for Antenna 4
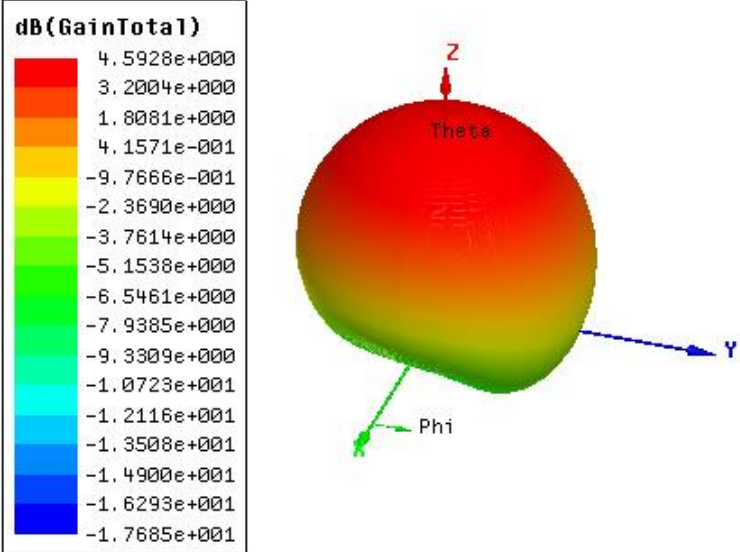

Fig: 12: Gain for Antenna 5
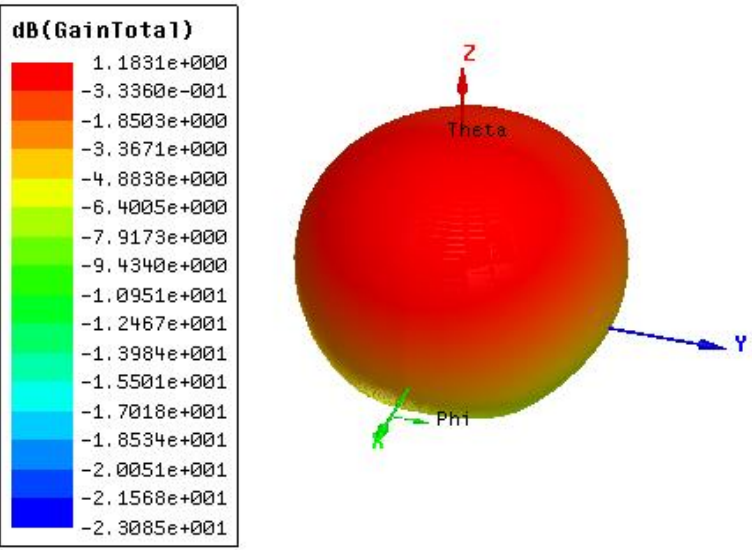

Fig: 13: Gain for Antenna 6
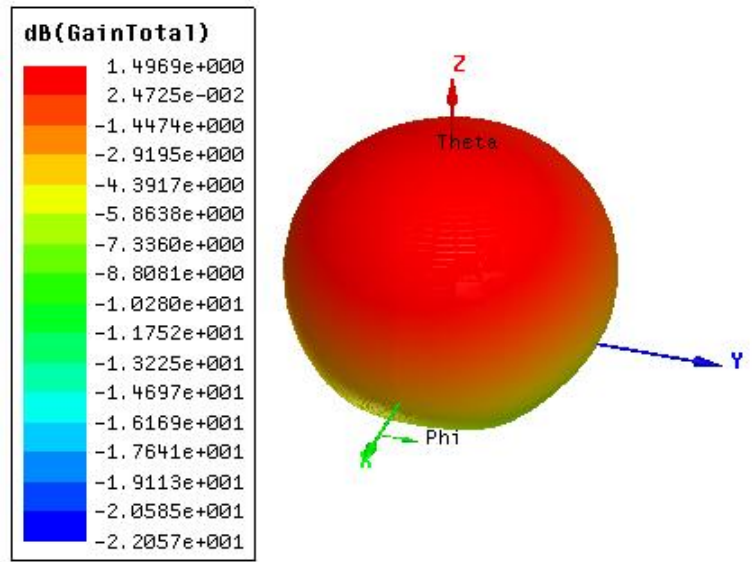

Fig: 14: Gain for Antenna 7

Fig: 10: Gain for Antenna 3 

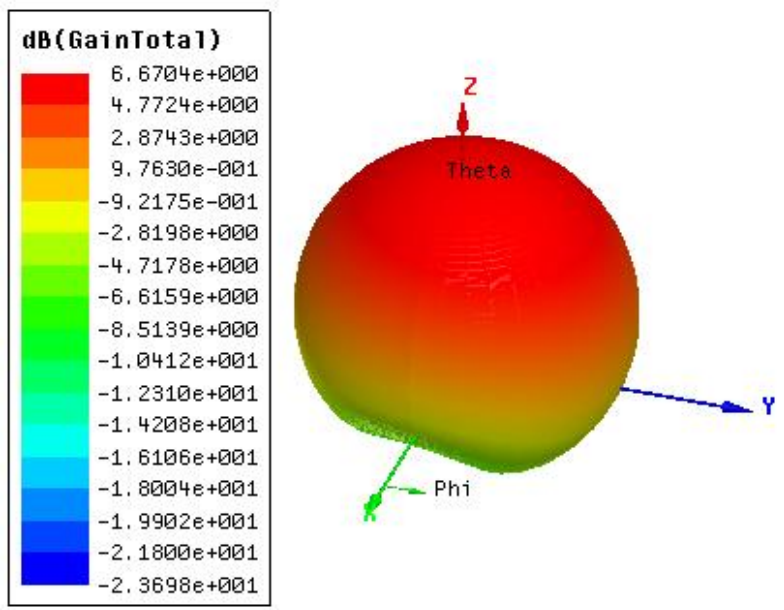

Fig: 15: Gain for Antenna 8
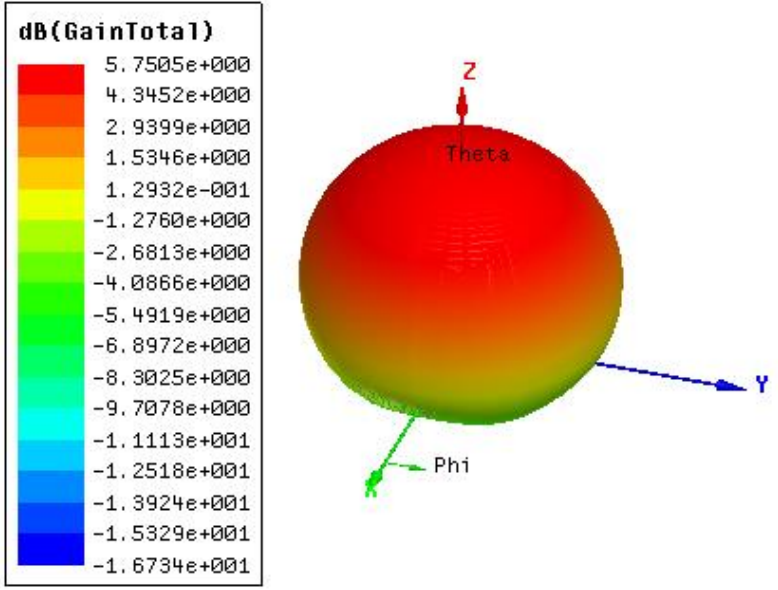

Fig: 16: Gain for Antenna 9
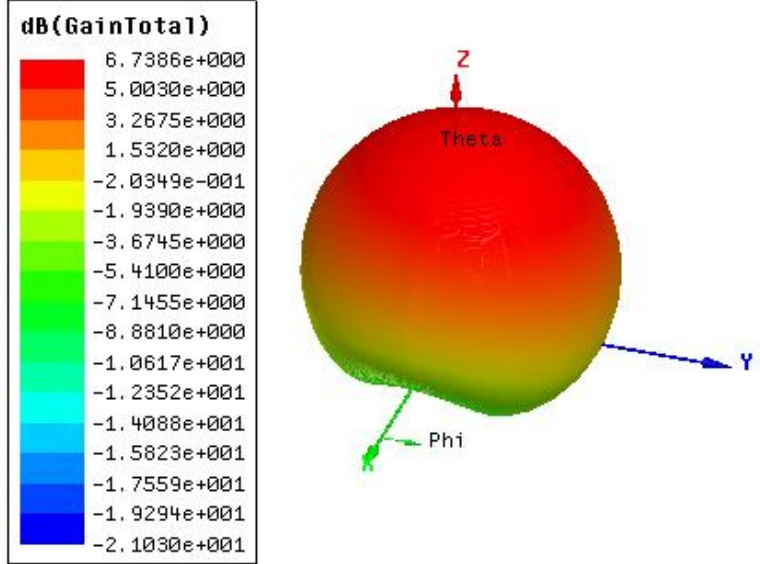

Fig: 17: Gain for Antenna 10

\section{dB (GainTota1)}
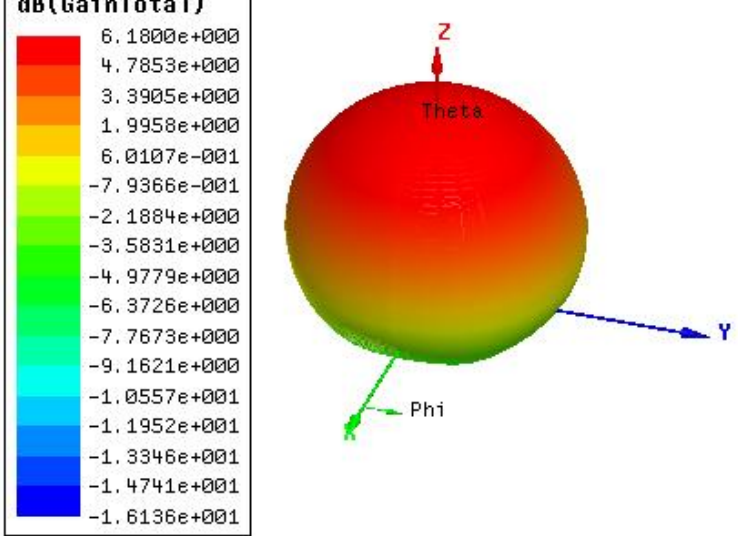

Fig: 18: Gain for Antenna 11

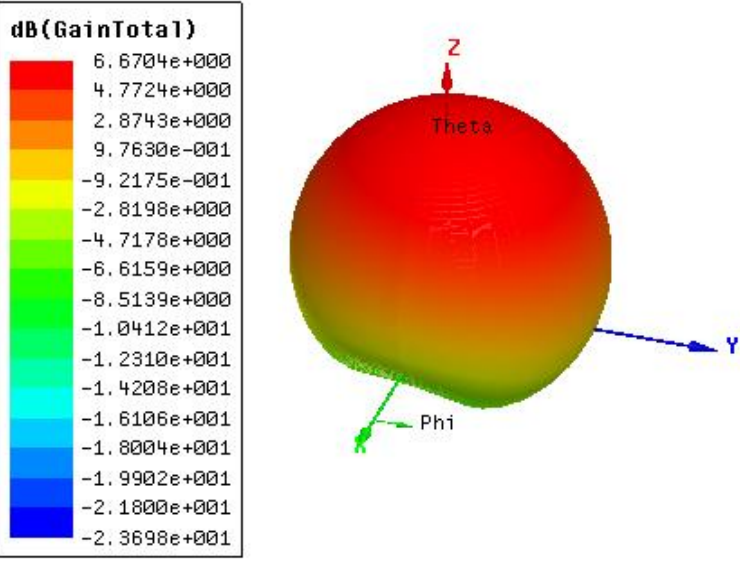

Fig: 19: Gain for Antenna 12

\subsection{Radiation Pattern}

The graphical representation of the electromagnetic power distribution in free space is defined as Radiation pattern.

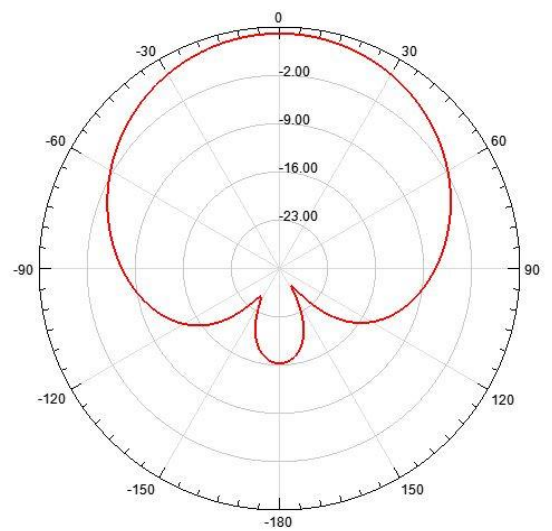

Fig: 20: Radiation Pattern for Antenna 1

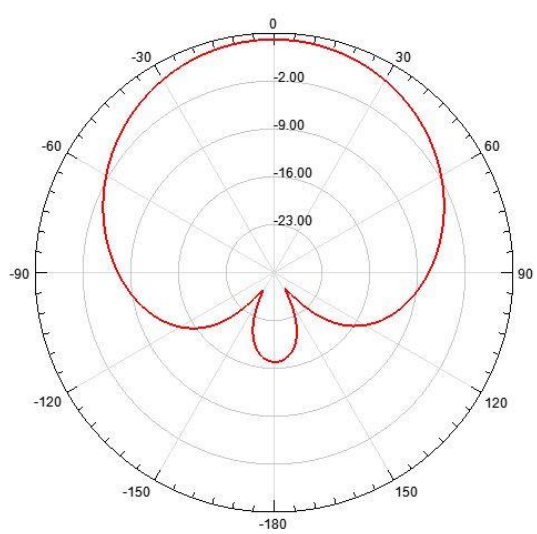

Fig: 21: Radiation Pattern for Antenna 2

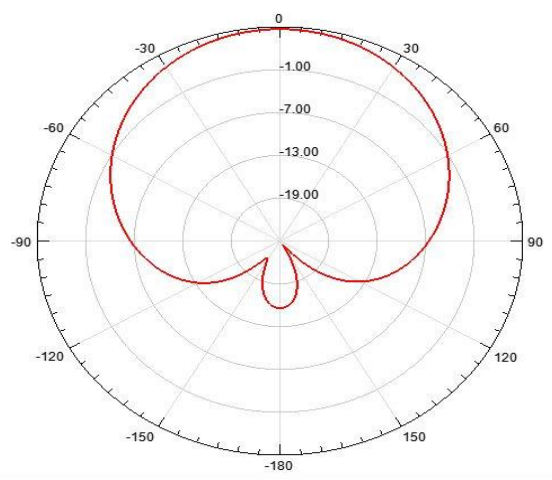

Fig: 22: Radiation Pattern for Antenna 3 


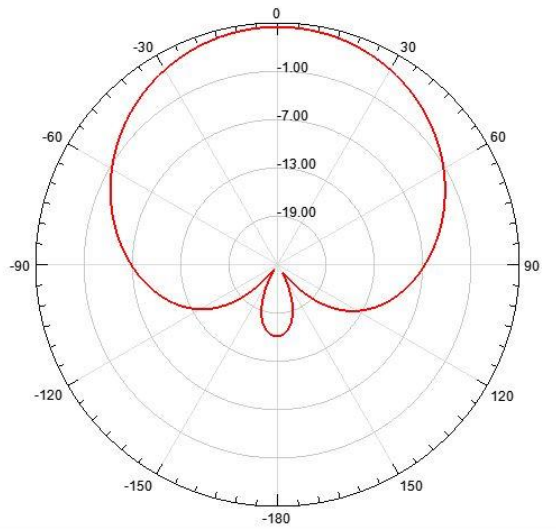

Fig: 23: Radiation Pattern for Antenna 4

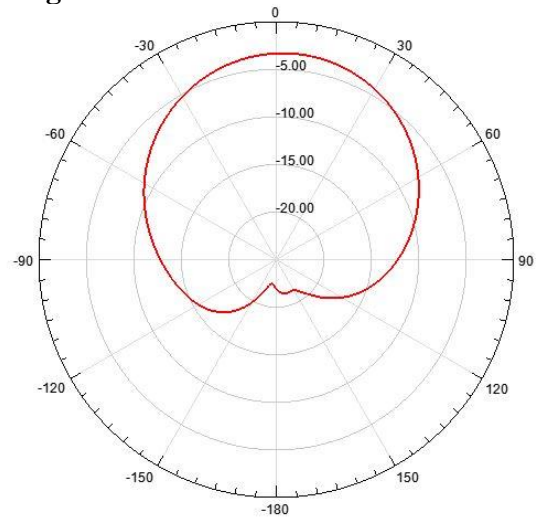

Fig: 24: Radiation Pattern for Antenna 5

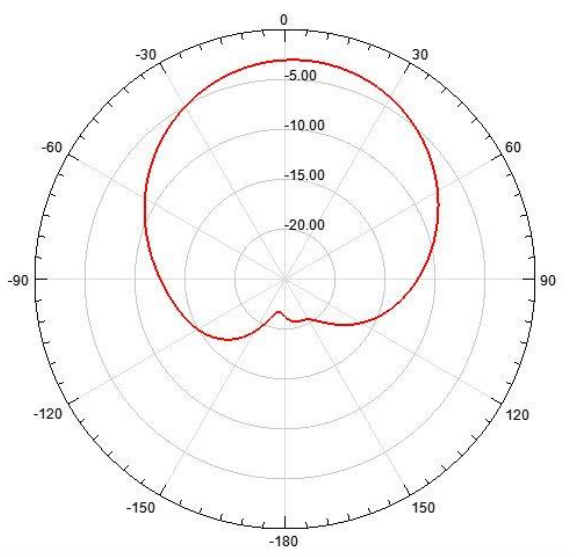

Fig: 25: Radiation Pattern for Antenna 6

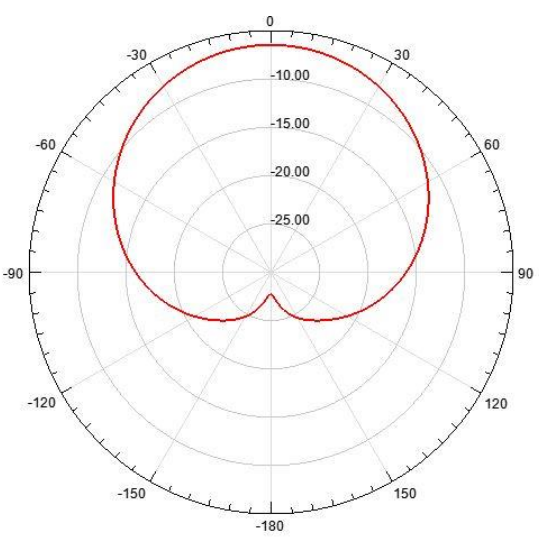

Fig: 26: Radiation Pattern for Antenna 7

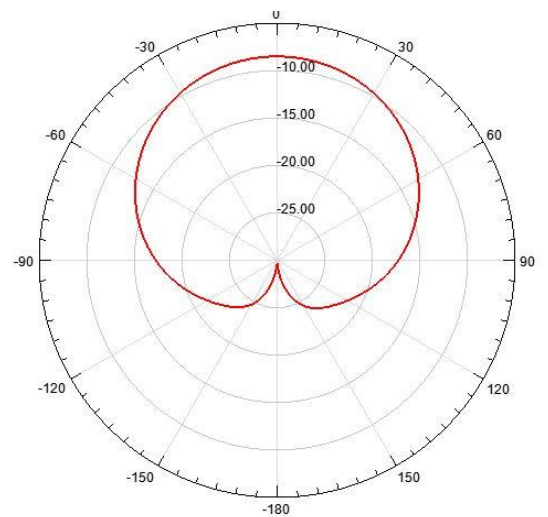

Fig: 27: Radiation Pattern for Antenna 8

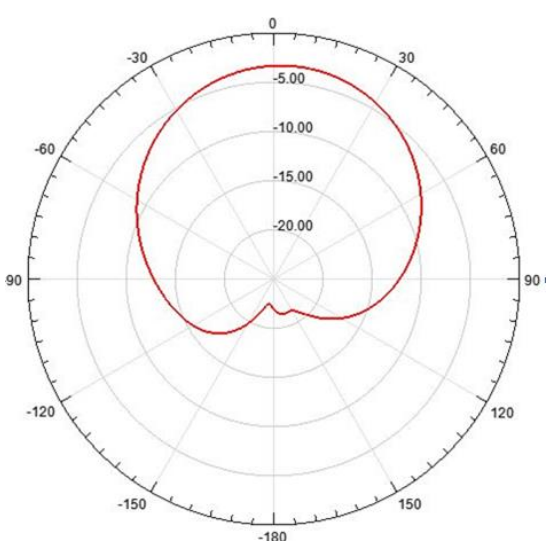

Fig: 27: Radiation Pattern for Antenna 9

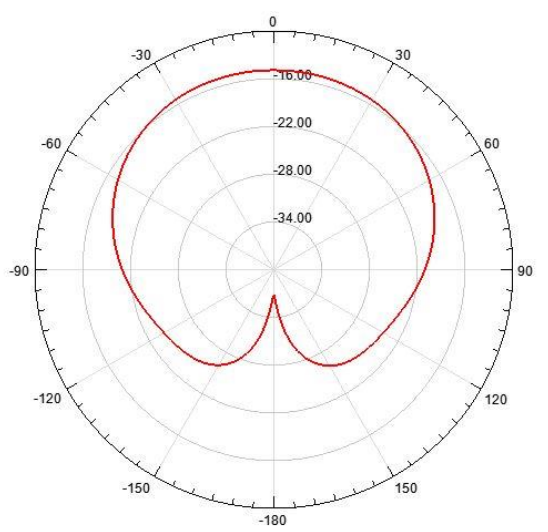

Fig: 28: Radiation Pattern for Antenna 10

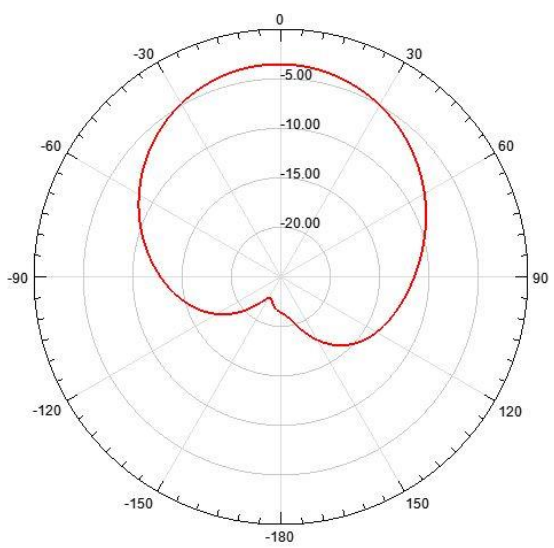

Fig: 29: Radiation Pattern for Antenna 11 


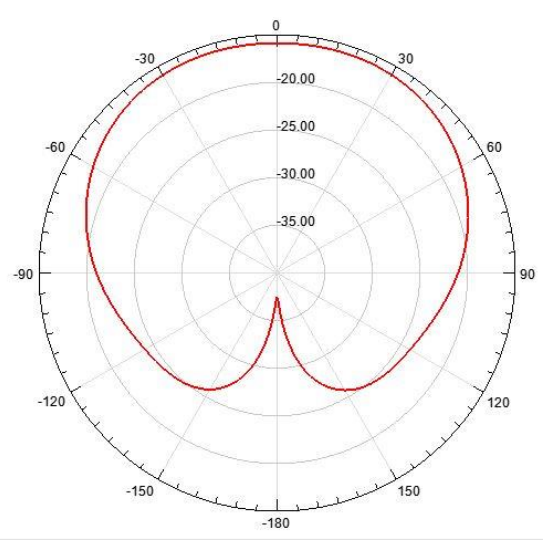

Fig: 30: Radiation Pattern for Antenna 12

\section{Comparative Analysis}

All models that are designed are compared along with their characteristics and has been presented. Actually, if it is seen, four antenna models are designed with three substrates each. The substrates that are used to design the four antenna types are as follows; (1) Rogers RT/duroid 5880 (tm) with Relative permittivity of 2.2, (2) FR4 EPOXY with relative Permittivity of 4.4, (3) Rogers RT/duroid $5880(\mathrm{tm})$ with Relative permittivity of 2.94 .

In table 3, four models designed using the substrate Rogers RT/duroid $5880(\mathrm{tm})$ has an average gain of $7 \mathrm{~dB}$ and efficiency of 98.percent has been noticed in the proposed models. The applications of the proposed models are for industrial, scientific and medical radio bands, and $\mathrm{Wi}-\mathrm{Fi}$.

\begin{tabular}{|c|c|c|c|c|c|c|c|}
\hline $\begin{array}{l}\text { Sub- } \\
\text { strate }\end{array}$ & $\begin{array}{l}\text { Mod } \\
\text { el } \\
\text { Type }\end{array}$ & $\begin{array}{l}\text { Operat- } \\
\text { ing Fre- } \\
\text { quency( } \\
\text { GHz) }\end{array}$ & $\begin{array}{l}\text { Re- } \\
\text { turn } \\
\text { Los } \\
\mathrm{s}\end{array}$ & $\begin{array}{c}\text { Band } \\
\text { width } \\
(- \\
10 \mathrm{~dB} \\
) \\
\mathrm{GHz}\end{array}$ & $\begin{array}{c}\text { Gai } \\
\mathrm{n}\end{array}$ & $\begin{array}{l}\text { Effi- } \\
\text { cien- } \\
\text { cy }\end{array}$ & $\begin{array}{c}\text { Pea } \\
\text { k } \\
\text { Gai } \\
n\end{array}$ \\
\hline \multirow{4}{*}{$\begin{array}{l}\text { Rog- } \\
\text { ers } \\
\text { RT/du } \\
\text { roid } \\
5880 \\
\text { (tm) } \\
\text { Per- } \\
\text { mit- } \\
\text { tivity } \\
=2.2\end{array}$} & $\begin{array}{l}\text { An- } \\
\text { ten- } \\
\text { na1 } \\
(-5, \\
0,-5)\end{array}$ & 2.37 & $\begin{array}{c}- \\
32.4 \\
01\end{array}$ & $\begin{array}{c}0.050 \\
5\end{array}$ & $\begin{array}{c}7.3 \\
065\end{array}$ & $\begin{array}{c}0.984 \\
06\end{array}$ & $\begin{array}{c}5.3 \\
282\end{array}$ \\
\hline & $\begin{array}{l}\text { An- } \\
\text { ten- } \\
\text { na2 } \\
(-5, \\
5,-5) \\
\end{array}$ & 2.37 & $\begin{array}{c}- \\
25.7 \\
983\end{array}$ & $\begin{array}{c}0.049 \\
7\end{array}$ & $\begin{array}{c}7.3 \\
384\end{array}$ & $\begin{array}{c}0.987 \\
58\end{array}$ & $\begin{array}{c}5.3 \\
599\end{array}$ \\
\hline & $\begin{array}{l}\text { An- } \\
\text { ten- } \\
\text { na3 } \\
(-5, \\
0,-5)\end{array}$ & 2.44 & $\begin{array}{c}- \\
32.4 \\
827\end{array}$ & 0.55 & $\begin{array}{c}7.2 \\
584\end{array}$ & $\begin{array}{c}0.982 \\
6\end{array}$ & $\begin{array}{c}5.4 \\
468\end{array}$ \\
\hline & $\begin{array}{l}\text { An- } \\
\text { ten- } \\
\text { na4 } \\
(-5, \\
5,-5)\end{array}$ & 2.44 & $\begin{array}{c}- \\
37.0 \\
901\end{array}$ & $\begin{array}{c}0.054 \\
1\end{array}$ & $\begin{array}{l}7.2 \\
835\end{array}$ & $\begin{array}{c}0.989 \\
26\end{array}$ & $\begin{array}{c}5.4 \\
785\end{array}$ \\
\hline
\end{tabular}

\begin{tabular}{|c|c|c|c|}
\hline Substrate & Model Type & $\begin{array}{c}\text { Operating Fre- } \\
\text { quency }(\mathrm{GHz})\end{array}$ & Return Loss \\
\hline \multirow{4}{*}{$\begin{array}{l}\text { Rogers RT/duroid } \\
6002 \text { (tm) } \\
\text { Permittivity }=2.94\end{array}$} & $\begin{array}{l}\text { Antenna1 (-5, } \\
0,-5)\end{array}$ & 2.082 & -21.0561 \\
\hline & $\begin{array}{l}\text { Antenna2 (-5, } \\
5,-5)\end{array}$ & 2.14 & -20.0216 \\
\hline & $\begin{array}{l}\text { Antenna3 (-5, } \\
0,-5)\end{array}$ & $2.09,2.65$ & $\begin{array}{l}(-20.3314) ; \\
(-18.8164)\end{array}$ \\
\hline & $\begin{array}{l}\text { Antenna4 (-5, } \\
5,-5)\end{array}$ & $2.14,2.7200$ & $\begin{array}{l}(-22.5) ;(- \\
20.5538)\end{array}$ \\
\hline
\end{tabular}

In table 4, four models designed using the substrate FR4 EPOXY has a gain ranging from $1 \mathrm{~dB}$ to $4 \mathrm{~dB}$ and efficiency ranging from 43.percent to 72 percent has been noticed in the proposed models. The applications of the proposed models are the band $3.4-3.55$ $\mathrm{GHz}$ was allocated for FWA for areas outside the main cities in Canada.

In table 5, four models designed using the substrate Rogers RT/duroid $5880(\mathrm{tm})$ has a gain of $6 \mathrm{~dB}$ and efficiency of 95 percent has been noticed in the proposed models. The applications of the proposed models are

\section{Conclusion}

The designed antenna provides a return loss of $-32.405 \mathrm{~dB}$. The antenna was designed and simulated using HFSS software. As noticed that by increasing the number of slots we could find improvement in the antenna parameters like gain and return loss, with increase in decrease in return loss which was obtained by simulation using HFSS15. Based on the substrate chosen and relative permittivity values, the antenna parameter values varied. We could observe that the antenna designed with lower relative permittivity has better efficiency than the antenna designed with more relative permittivity. Twelve outline of antenna is projected. The first outline is rectangular patch antenna configuration. The second outline is rectangular antenna structure with change in feed position. The third outline is rectangular antenna structure with original feed position and with some cutting edges on the patch. The Fourth outline is rectangular antenna structure with change in feed position and with some cutting edges on the patch. This design outline is repeated with two more substrate and analyzation and simulation is displayed.

\section{Acknowledgements}

The authors especially thank the support given from Department of Science and Technology (DST), Government of India through the funded project with F. No: SB/FTP/ETA-0175/2014. The authors also thank the management of KL University for supporting and encouraging this work by providing the facilities in

\begin{tabular}{|c|c|c|c|c|c|c|c|}
\hline Substrate & Model Type & $\begin{array}{l}\text { Operating Fre- } \\
\text { quency }(\mathrm{GHz})\end{array}$ & Return Lossnt & $\begin{array}{l}\text { Bordendind } \\
10 \mathrm{~dB}) \mathrm{GHz}\end{array}$ & earchinamlectro & maspeticency & REseak ECH \\
\hline \multirow{3}{*}{$\begin{array}{l}\text { FR4 EPOXY } \\
\text { Permittivity }=4.4\end{array}$} & $\begin{array}{l}\text { Antenna1 (-5, } \\
0,-5)\end{array}$ & 3.43 & \multicolumn{2}{|c|}{-15.891Reference 41} & 1.1831 & $\begin{array}{l}0.43725 \\
0.66836\end{array}$ & $\begin{array}{l}1.4298, \\
3.4779\end{array}$ \\
\hline & $\begin{array}{l}\text { Antenna2 }(-5 \text {, } \\
5,-5)\end{array}$ & $2.21,3.43$ & $\begin{array}{c}(-13.4812) ;(-1 \\
13.8713)\end{array}$ & \multicolumn{2}{|c|}{ 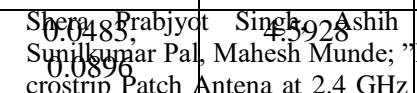 } & $\begin{array}{l}\text { Singhy.8784epa } \\
\text { Desjign and Fab } \\
\text { for WLAN App }\end{array}$ & $\begin{array}{l}\text { Up.ostsay, } \\
\text { ticationg } 93 \mathrm{Mi}- \\
\text { dication using }\end{array}$ \\
\hline & $\begin{array}{l}\text { Antenna3 (-5, } \\
0,-5)\end{array}$ & $1.79,3.5$ & $\begin{array}{c}(-11.4319) ;(- \\
25.5499)\end{array}$ & \multicolumn{2}{|c|}{$\begin{array}{l}\text { HASBO0 IOSR Journall. } \$ 969 \text { ectro } \\
\text { neering, AETM- } 16 \text {. } \\
\text { Houda Werfell.. Khaoula Tavari. }\end{array}$} & $\begin{array}{c}\text { nics } \mathrm{aA} \$ \mathbf{1} \text { 17\%mun } \\
0.64404 \\
\text { Mondher Chaol }\end{array}$ & $\begin{array}{l}\text { catibs54 E6gi- } \\
3.4837 \\
\text { ii. Mongi La- }\end{array}$ \\
\hline
\end{tabular}


Patch Antenna", $2^{\text {nd }}$ International Conference on Advanced Technologies for Signal and Image Processing- ATSIP' 2016 March 21-24, 2016, monastir, Tunisia.

[3] Custodio Peixeiro; "Microstrip Patch Antennas- An Historical Perspective of the Development", IEEE Transactions, Antennas Propagations, 2011.

[4] Asokan V, Thilagam S, Vinoth Kumar K; "Design and Analysis of Microstrip Patch Antenna for $2.4 \mathrm{GHz}$ ISM Band and WLAN Application", IEEE sponsored $2^{\text {nd }}$ International Conference on Electronics and Communication System (ICECS 2015).

[5] Keith R. Carver, James W. Mink; "Microstrip Antenna Technology", IEEE Transactions on Antennas and Propagation, Vol. AP29, No. 1, January 1981

[6] Muhammad Aamir Afridi; "Microstrip Patch Antenna - Designing at $2.4 \mathrm{GHz}$ Frequency", Biological and Chemical Research, Volume 2015, 128-132, Science Signpost Publishing

[7] Km. Kamakshi, Ashish Singh, Mohammad Aneesh and J. A. Ansari; "Novel Design of Microstrip Antenna with Improved Bandwidth", International Journal of Microwave Science and Technology, Volume 2014 (2014), Article ID 659592, 7 Pages

[8] Vasujadevi Midasala, Dr. P. Siddaiah; "Microstrip Patch Antenna Array Deisgn to Improve Better Gains", Elsevier, International Conference on Computational Modelling and Security (CMS 2016)

[9] Toshihisa Kamei, Hiromi Shima, Syotaro Fukuda, Seishiro Ishii; "A Linear Array Antenna of Microstrip Patch Antennas Fed by the Open-end of Coplanar Waveguides", Scientific Research Publishing, Wireless Engineering and Technology, 2017, 8, 37 49

[10] Qian, Yongxi, et al. "A microstrip patch antenna using novel photonic band-gap structures." Microwave Journal, Jan. 1999, p. 66

[11] Bai Cao Pan and Tie Jun Cui; "Broadband Decoupling Network for Dual-Band Microstrip Patch Antennas", IEEE Transactions on Antennas and Propagation, Vol. 65, No. 10, October 2017

[12] Steven Weigand, Greg H. Huff, Kankan H. Pan and Jennifer T. Bernhard; "Analysis and Design of Broad-Band Single-Layer Rectangular U-Slot Microstrip Patch Antennas", IEEE Transactions on Antennas and Propagation, Vol. 51, No. 3, March 2003

[13] S. Daya Murali, K.Ch. Sri Kavya, Sarat K Kotamraju, R. Sai Divya, Y. Satish, K. Pradeep Chandra, N. Sri Keerthi, G. Jaya Sree, "Size Reduction of Yagi-Uda Antenna by Altering the Diameter and Spacing between the Elements", International Journal of Applied Engineering Research, ISSN 0973-4562 Volume 9, Number 22 (2014) pp. 12011-12022.

[14] Akella Jharesh, K. Ch. Sri Kavya and Sarat K Kotamraju, "Design and simulation of cylindrical and sheet corner reflector Yagi-Uda antennas for amateur radio application", ARPN Journal of Engineering and Applied Sciences, ISSN 1819-6608, Vol. 10, No. 6, June 2015, pp. 4527-4532.

[15] K.Ch. Sri Kavya, Sarat K Kotamraju and Sekuri Sukumar, "Comparative Analysis of Slim Jim Antenna for Ham Radio Applications", ARPN Journal of Engineering and Applied Sciences, ISSN 1819-6608, Vol. 9, No. 10, October 2014, pp. 1936-1945.

[16] Manjulatha V and K.Ch. Sri Kavya, "Implantable Antennas for Biomedical Applications", ARPN Journal of Engineering and Applied Sciences, ISSN 1819-6608, Vol. 11, No. 9, May 2016, pp. 5632-5636.

[17] Kalyan, S., Sri Kavya, K.C., Kotamraju, S.K., “A reconfigurable beam steering linear phased array antenna for $\mathrm{Ku}$ band satellite communication using graphing method", (2017) Journal of Advanced Research in Dynamical and Control Systems, 2017 (Special Issue 2)

[18] Tej, D.R., Sri Kavya, K.Ch., Kotamraju, S.K., "Development of phased array antenna for c-band applications using HFSS", (2017) Ponte, 73 (9), pp. 298-306. 